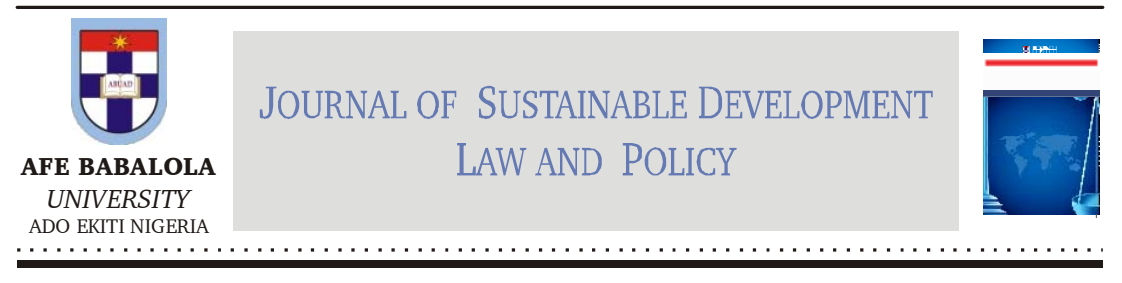

\title{
LARGE-SCALE LAND ACQUISITION AND HUMAN RIGHTS AT THE CROSSROADS: QUEST FOR A RIGHTS-BASED APPROACH TO LAND ADMINISTRATION IN ETHIOPIA
}

\author{
Abiyot Mogos Dabala*
}

\begin{abstract}
Large-scale land investment through a form of forceful acquisition, dubbed "land grabbing", is a perennial concern for local community and indigenous peoples in Africa, particularly in Ethiopia. This article explores the human rights impacts of such large-scale land acquisition in Ethiopia and discusses ways of ameliorating its effects. It demonstrates how largescale land acquisition in the country undermines substantive rights of the local and indigenous peoples, including land rights, right to food, development, culture, self-determination, labour rights, environmental rights, as well as their procedural right to public participation, prior informed consent, access to information and justice, all of which are recognized under international instruments, and the constitution of the Federal Democratic Republic of Ethiopia (FDRE). The article advocates for a human rights-based approach to large-scale land acquisition regime that respects and integrates the aforementioned substantive and procedural rights of local and indigenous peoples. This also involves government's obligation to implement effective human right impact assessment, efficient monitoring, evaluation, dispute resolution mechanism, and empowering local community and other stakeholders to safeguard the rights of affected community. By so doing, the country
\end{abstract}

* LL.B, LL.M in International Economic and Business Law from Haramaya University, Ethiopia; Lecturer of Law at Mettu University, Ethiopia and can be reached at abiyot00@gmail.com 
can mobilize the large-scale land investment for sustainable development without compromising the rights of local and indigenous peoples.

Keywords: Ethiopia, Human Rights, Large-Scale Land Acquisition.

DOI: https://dx.doi.org/10.4314/jsdlp.v10i2.3

\section{INTRODUCTION}

Human rights are the fundamental rights and freedoms that all human beings naturally enjoy by virtue of being human. ${ }^{1}$ They are "universal legal guarantees protecting individuals and groups against evictions and omissions that interfere with their fundamental freedom, entitlement, and human dignity". ${ }^{2}$ Ethiopia is a signatory to a series of international human rights instruments that provide various contexts of the inalienable and inviolable human rights, and impose a duty to respect, protect and promote these rights on states. ${ }^{3}$ These human rights standards, as reflected in international human rights treaties and principles, guide all aspects of development programming and set the realization of human rights as the main objective of development policy and programme. ${ }^{4}$ In light of this, a development programme of a given state should respect and target the actualization of the human rights of individuals and the local community. ${ }^{5}$ Yet, the new wave of large-scale land investment also dubbed "land grabbing" in the media and critical literature, reportedly causes adverse impacts on the human rights of local communities in Ethiopia and in the African continent.

1 United Nations Human Rights Office of High Commissioner, "What are human rights?"<http://www.ohchr.org/EN/Issues/Pages/WhatareHuman Rights.aspx $>$ accessed on 20 June 2019.

2 HRBA Portal < https://hrbaportal.org/faq/what-is-a-human-rights-basedapproach $>$ accessed 20 June 2019.

3 Ibid.

4 HRBA portal < https://hrbaportal.org/faq/how-do-human-rights-guideprogramme-formulation $>$ accessed on 20 June 2019.

5 This way of linking development programme with human right is commonly termed as human-right-based approach.

6 "Land grabbing" is defined as "a global enclosure movement in which large areas of arable land change hands through deals often negotiated between host governments and foreign investors with little or no participation from local communities who depend on access to those lands for their livelihoods". See Oliver De Schutter, "The Green Rush: The Global Race for Farmland and Rights of Land Users" [2011] HILJ 503, 504. 
Large-scale land acquisitions constitute a new trend that emerged from the 2008 global food crisis. ${ }^{7}$ The main target of these recent waves of "foreign investment in land are sub-Saharan African countries such as Cameroon, Ethiopia, Democratic Republic of Congo, Madagascar, Mali, Somalia, Sudan, Tanzania and Zambia". ${ }^{8}$ Such aggressive, large-scale land acquisitions for commercial agriculture in Africa have attracted worldwide debate. Proponents view large-scale land investments as "opportunities for development, given their potential for creating infrastructure and employment, increasing public revenues and improving farmers' access to technologies and credit". ${ }^{9}$ However, critics express concern about the negative impact of such developments on the human rights of local communities, land rights, as well as consideration for indigenous communities and the environment. ${ }^{10}$ Others claim that the impacts of such "large-scale land investments have become more threatening in Africa due to lack of legal and institutional mechanisms to alleviate the spill over risks of such investments". ${ }^{11}$

Ethiopia represents a typical example of large-scale land investment and its human right challenges, particularly in Africa. The government of Ethiopia has warmly welcomed such large-scale land investments ${ }^{12}$ allocating huge hectares of land at very low lease price. It has been reported that by January 2011, the government had transferred 3,619,000 hectares of land to investors. ${ }^{13}$ The land transferred to large-scale land investors, besides the land already allocated, has been planned to increase to 3.3 million hectares by $2015 .{ }^{14}$ Therefore, by 2016 , at least an estimated 7 million hectares of agricultural land would have been transferred to investors. Total land transferred to investors thus account for about 38

7 Special Rapporteur on Right to Food, Large-Scale Land Acquisitions And Leases: A Set of Minimum Principles And Measures To Address The Human Rights Challenge, UN Doc A/Hrc/13/33/Add.2, 28 December 2009, 5, Para. 11.

8 Ibid.

9 Ibid.

10 Evadne Grant \& Onita Das, "Land Grabbing, Sustainable Development and Human Rights" [2015] Transnational Environmental Law, 289; Dessalegn Rahmato, "Land to investors: Large-Scale Land Transfers in Ethiopia, Forum for Social Studies" [2011]; Schutter (n.6).

11 Semahagn G. Abebe, "The Need to Alleviate the Human Rights Implications of Large-scale Land Acquisitions in Sub-Saharan Africa"[2012] GoJIL 873, 879.

12 Large-scale means 2000 hectares or more. See Rahmato(n.10)53.

13 The Oakland Institute, "Understanding Land Investment Deals in Africa: Country Report: Ethiopia, 2011, p. 18.

14 Rahmato (n.10)22. 
per cent of land utilized by smallholders. ${ }^{15}$ The main investors are foreign investors, the largest foreign holding being Karuturi Company of India, which has been given 0.3 million hectares of land in Gambella and 11,000 in Bako district of Oromia. ${ }^{16}$

Ethiopia has been chosen for agricultural investment considering the availability of cheap labour and arable land, her strategic location and the Government's support to boost foreign investment in agriculture. ${ }^{17}$ The Government of Ethiopia strategically promoted large-scale agricultural investment and this is reflected through its programmes such as the "Agricultural Development-Led Industrialization (ADLI)", ${ }^{18}$ its perceived developmental state ideology, ${ }^{19}$ investment legislation ${ }^{20}$ as well as the five-year Growth and Transformation Plan. Ethiopia's Growth and Transformation Plan II (GTP II: 2015-2020) clearly promotes commercial agricultural investment. ${ }^{21}$ Government's initiative to support commercial farming in Ethiopia "displays three primary objectives: (i) boost productivity; (ii) link smallholder farmers with new technologies and markets; and (iii) create of job opportunities for rural youth". ${ }^{22}$ Conversely, there is widespread concern that such investments operate at the expense of the human rights of the local community. ${ }^{23}$

15 Ibid.

16 Ibid 12

17 The Oakland Institute (n.13)14.

18 As its name indicates, ADLI is long-term strategy to achieve faster growth and economic development by employing technologies, fertilizers, improved seeds and cultural practices.

19 Developmental State refers to state which makes it its primary goal to enhance economic growth and even denies human rights as condition for rapid economic development. The Ethiopian government has shifted to this ideology since 1995. See Befekadu W/ Gabriel, EPRDF, Developmental State and Rent Seeking < http://www.meleszenawi.com/wpcontent/uploads/2013/03/ EthiopiaEPRDF-Developmental-State-and-Rent-Seeking.pdf $>$ accessed on 20 June 2019).

20 See Investment Proclamation No 769/2012; Investment Incentive and Investment Areas Reserved for Domestic Investor's Regulation No 270/2012; Agricultural Investment Land Administration Agency Establishment Regulation No. 283/ 2013, which clearly supports and facilitate commercial agricultural investment.

21 Dawit Alemu and Gezahegn Ayele, "Future agriculture, Ethiopian Agricultural Investment Policy"[2018] < https://www.futureagricultures.org/blog/ethiopiacommercial-farming-investment-and-policy/>accessed on 25 June 2019.

22 Ibid.

23 See inter alia Oakland Institute (n.12); Rahmato(n.14); Human Rights Watch "Waiting here for Death: Forced Displacement and 'Villagization' in Ethiopia's 
This article explores the human right implication of large-scale land investment in Ethiopia and pinpoints the pressing need to adopt a human rights approach to large-scale land investment governance in the country as a way out. In furtherance of this, section 2 reviews and analyses the human rights implication of relevant international instruments and soft laws applicable to large-scale land investment. Section 3 exposes the impact of large-scale land acquisition on the human rights of Ethiopians. Section 4 stresses adoption of human right based approach to land acquisition to achieve a win-win outcome. Section 5 is the conclusion.

\section{SUPPORTING INTERNATIONAL INSTRUMENTS, SOFT LAWS AND PRINCIPLES}

\subsection{The International Bills of Human Right}

The "International Bill of Rights" consitutes Universal Declaration of Human Rights (UDHR), International Covenant on Civil and Political Rights (ICCPR), and International Covenant on Economic, Social, and Cultural Rights (ICESC). This Bill of Rights contains a variety of civil and political rights as well as economic, social and cultural rights which can conveniently be grouped into procedural and substantive rights. The main substantive rights of the bill include: right to life, freedom from slavery, freedom from torture, right to privacy, freedom of thought, conscience and religion, freedom of assembly and association, right to property, right to health, right to self-determination, right to social security, right to work, right to rest and leisure, right to an adequate standard of living, right to education, right to participate in the cultural life and others. ${ }^{24}$ The main procedural rights include right to access to information, right to public participation in decision-making, and right to access to justice and effective remedy for rights violations. ${ }^{25}$

Gambella Region" [2012] < http://www.hrw.org/reports/2012/01/16/waitinghere-death > accessed on June 27 2019. In this regard, a prominent opposition party leader, Bekele Garba, also known for his motto "our land is our bone" bitterly opposed the ongoing large-scale land grabbing in the county.

24 See the list of civil and political rights and freedoms under Articles 3-21 of UDHR, and social and cultural rights listed under Articles 22 to 27 of UDHR. These rights are also listed and detailed under the corresponding provisions of ICCPR and ISESCR.

25 See Article 19 of UDHR \& Article 19 of ICCPR; Article 21 of UDHR \& Article 25 ICCPR, and Article 8 of UDHR, respectively. 
The Bills require the states to respect, protect and fulfil the human rights of individuals and groups within their territory. ${ }^{26}$ This includes the duty to protect against human rights abuse by third parties, including business enterprises. The principles and standards derived from these bills of rights along with all other specific treaty signed to reinforce the rights contained in the bills, including the relevant ILO conventions and declarations ${ }^{27}$ guide all policies and programming in all sectors and, hence, can be used to discipline human rights impacts of large-scale agricultural investment. ${ }^{28}$ This is because the rights are considered inalienable and inviolable, thus requiring universal respect.

\subsection{Declaration on Right to Development}

The declaration on right to development ${ }^{29}$ is a proclamation of the right to development. It defines right to development as "inalienable human right by virtue of which every human person and all peoples are entitled to participate in, contribute to, and enjoy economic, social, cultural and political development, in which all human rights and fundamental freedoms can be fully realized". ${ }^{30}$ The basic requirements of the right to development under the declaration includes putting people at the centre of development, public participation, non-discrimination, fair distribution of benefits of development, self-determination and sovereignty over natural resources, and the creation of favourable conditions for enjoyment of other civil, political, economic, social and cultural rights. ${ }^{31}$ Under the declaration, States have the right and the duty to formulate appropriate national development policies, legislation and other steps which aim at the constant improvement and realization of the right to development. ${ }^{32}$

26 Article 2 of both ICESCR and ICCPR stresses state's obligations to respect, protect and take steps for realization of the right contained in the respective conventions.

27 For instance, the 1998 ILO Declaration on Fundamental Principles and Rights at Work can provide labour obligation for responsible large-scale land investment.

28 UN Office of High Commissioner for Human Rights, "Land grabbing must be disciplined: UN expert on food" [2009] < http://reliefweb.int/report/ethiopia/ land-grabbing-must-be-disciplined-un-expert-food > accessed on June 25/2019.

29 Declaration on the Right to Development, (adopted 4 December 1986 UNGA Res 41/128(DRD).

30 RRD, article 1.

31 DRD, articles 1-10.

32 DRD, Articles 3 and 10. 


\subsection{Declaration on the Rights of Indigenous Peoples}

Declaration on the Rights of Indigenous Peoples ${ }^{33}$ reaffirmed the vulnerability and special need of indigenous people and adopted set of rights available for them. The core rights of indigenous people that could be invoked in relation to development programme under the declaration includes right to self-determination and self-government, right to revitalize their culture and have access to their religious and cultural sites, right not to be forcibly removed from their lands without free, prior and informed consent, right to full participation and consultation before implementation measures affecting them, right to own, use, develop, conserve and control the lands they have traditionally owned or used, right to determine and develop priorities and strategies for exercising their right to development, and right to free, and informed consent prior to the approval of projects affecting their lands, territories and other resources. ${ }^{34}$ These rights of indigenous people shall be respected in all course of development programme affecting the indigenous people, including large-scale land acquisition.

\subsection{Declaration on the Rights of Peasants}

Reaffirming vulnerability in the development process and recognizing the need for greater protection of the human rights of peasants and other people working in rural areas, the UN General Assembly adopted Declaration on Rights of Peasants and Other People Working in Rural Areas in 2018. ${ }^{35}$ The core right of peasants under this Declaration includes the right to determine and develop priorities and strategies to exercise their right to development; right to equal access to use and management of land and natural resources, and to equal or priority treatment in land and agrarian reform and in land resettlement schemes; right to decent employment, equal remuneration and social protection benefits, and to have access to income generating activities; right to adequate food and fundamental right to be free from hunger; right to information; right to effective remedy and access to justice for infringements of their human rights; right to public participation and full consultation; right to benefit

33 Declaration on the Rights of Indigenous Peoples (adopted 13 September 2007 UNGA Res 61/295).

34 Declaration on the Rights of Indigenous people, Articles, 3, 4, 10, 18, 19, 23, $26,29 \& 32$.

35 Declaration on the Rights of Peasants and Other People Working in Rural Areas, (Adopted 30 October 2018 UNGA Res A/C.3/73/L.30). 
directly from social security programmes; and right to be free from all forms of violence. ${ }^{36}$ Article 2 of the Declarations requires states to respect, protect, and take appropriate steps to fulfil or achieve the progressive realization of rights of peasants and other people working in rural areas.

\subsection{UN Guiding Principles on Business and Human Rights}

This UN Guiding Principles on Business on Human Rights ${ }^{37}$ rest on three pillars, namely, to protect, respect and remedy frameworks that clarify the human rights duties of states and companies under the existing human rights instruments. The protect framework imposes on states the duty to protect human rights against third-party interference, including interference from business actors. This duty requires taking appropriate steps to prevent, investigate, punish and redress human rights violations through effective policies, legislation, regulations and adjudication..$^{38}$ In addition to the state duty to protect, States (including all public bodies and agencies) also have a duty themselves to respect human rights. The respect framework imposes an obligation on businesses to: "(a) Avoid causing or contributing to adverse human rights impacts through their own activities, and address such impacts when they occur; and (b) Seek to prevent or mitigate adverse human rights impacts that are directly linked to their operations, products or services." ${ }^{39}$ The remedy framework asserts the need for effective remedies, including judicial fora and nonjudicial grievance resolution mechanisms. ${ }^{40}$ While not legally binding, the guiding Principles received wide acceptance at national level.

\subsection{FAO Principles for Responsible Agricultural Acquisition}

The principle for responsible agricultural investment that respects rights, livelihoods and resources ${ }^{41}$ contains seven set of principles applicable to

36 See Articles 2, 3, 4, 5, 10, 11, 12, \& 15 of the Declaration on the Rights of Peasants.

37 UN Guiding Principles on Business and Human Rights: Implementing the United Nations "protect, respect and remedy" framework,[2011] UN Doc. A/HRC/ $17 / 31$.

38 Ibid. principle 1.

39 Ibid 13

40 See general principles of UN Guiding Principle on Business and Human Right.

41 FAO, IFAD, WB, \& UNACTAD Principles for Responsible Agricultural Investment that Respects Rights, Livelihoods and Resources [2010] (Extended Version) (FAO Principles]. 
large-scale land acquisition. These seven principles include: respecting land and resources rights, ensuring food security, good governance and transparency, public participation and consultation, ensuring responsible agricultural investment that respect rule of law and best practice, and ensuring social and environmental sustainability. In its discussion on principle 1 relating to "ensuring land and resource right", the instrument strictly circumscribed use of expropriation of the land before it can be transferred to private investors and calls for prompt and fair compensation. The principles are agreed to form a guiding framework for national investment policy making, and possibly codes of best practices that shall be adhered to by state and companies.

\subsection{AU Guiding Principles on Large-Scale Land Investments in Africa}

These guiding principles ${ }^{42}$ are dedicated to address challenges of largescale land investment in Africa and ensure that investments in land benefit Member States and key stakeholders. ${ }^{43}$ The fundamental principles for large-scale land investment provided under the guide include: respect human rights of communities, contribute the national plan and strategy for sustainable agricultural development, the decision based on principles of good governance and prior informed participation of affected community, respect land rights and benefit of women, maximize benefit while minimizing economic, financial, social and environmental costs to the community, and the need for cooperation, collabouration and mutual accountability to ensure that large-scale land investment beneficial to African economies and their people. ${ }^{44}$ The Guiding Principles serve as basis for commitment, solidarity and collective responsibility by governments, stakeholders and investors to improve the governance of large-scale land based agricultural investments in Africa. ${ }^{45}$

\section{IMPACTS OF LARGE-SCALE LAND ACQUISITION ON THE HUMAN RIGHTS OF ETHIOPIANS}

The wave of large-scale land investment in Ethiopia posed considerable

42 African Union Guiding Principles on Large-Scale Land-Based Investments in Africa [2014] (AU principles).

43 Ibid 1.

44 AU Principles, principle 6.

45 Ibid 4. 
human right impacts on local community, especially to the indigenous peoples. The perpetrators are both government and the investor. The government violates human right in the course facilitating such largescale land investment. The investors engage themselves directly or indirectly in suppression of human rights to ensure continued maintenance of regimes favourable to their investments. The threatened rights constitute both substantive and procedural rights recognized under the relevant international instruments and the FDRE constitution. This section scrutinizes frequently invoked human right impacts of large-scale land investment in Ethiopia based on a recent report, literatures, and the relevant human right instruments, standards and principles.

\subsection{The Core Substantive Human Rights at Stake}

\subsubsection{The Right to Land}

Despite the misconception that no international human right law recognizes the right to land, it is acknowledged under several binding and non-binding international human rights instruments as an implied right. ${ }^{46}$ "Land is crucial for the enjoyment of human rights, including the right to food, right to adequate standard of living ... to development [and] property, and it is indispensable to exercise the right to selfdetermination" and right to culture. ${ }^{47}$ Moreover, the right to land features prominently in the Declaration on Rights of Peasants ${ }^{48}$ and Declaration on rights of indigenous people. ${ }^{49}$ What is more, land right is clearly recognized under FDRE constitution ${ }^{50}$ and other land legislations. This right to land includes right to acquire land without payment, right to not be evicted from possessions, right to use land for agricultural production without time limitation, the right to transfer their land use rights to family members through inheritance or donation, and the right to rent up to half of their land holding to other persons. ${ }^{51}$

46 H.A Tura, "Land rights and land grabbing in Oromia, Ethiopia" [2018] Land Use Policy 247, 248.

47 Ibid.

48 Article 17 of the Declaration on the right of peasant expressly states that Peasants and other people living in rural areas have the right to land.

49 Article 10 of the Declaration on right of indigenous peoples.

50 Article 40(4\&5) of the 1995 FDRE constitution states peasants and pastoralists have the right to acquire land free of charge, the right to not be evicted from their possessions and a right to use the land for an indefinite period.

51 See Federal Rural Land Proclamation No. 456/2005, Articles 5, 7. 
Against these constitutional and international frameworks on right to land, the practice of large-scale land acquisition seriously undermines land right of local community and indigenous people in Ethiopia. To illustrate, it has been reported that large-scale land acquisition has led "to forceful displacement and relocation of 45,000 indigenous households in Gambella and 90,000 households in Benishsngul Gumuz of Ethiopia through a programme known as 'villagization and resettlement"'. ${ }^{52}$ There is also a report from Bako in Oromia that "many farmers lost land [up] to 10,000 hectares [at] Karuturi farm. ${ }^{53}$ In most of cases, the relocation was made without consultation and adequate compensation on the grounds of lack of title deed. ${ }^{54}$ This approach to large-scale land acquisition and investment in the country undermines farmer's right to land by arbitrary evicting them, annulling their right to use and transfer their right to their descendants, and denying their right to property, which is essential to their livelihood.

\subsubsection{The Right to Food}

The right to food is clearly recognized as a human right under the international bill of rights and other soft laws. ${ }^{55}$ In Ethiopia, although the FDRE constitution lacks clear provision on right to food, the right could be enforced implicitly as part of other rights protected by the constitution ${ }^{56}$ or through the instrumentality of international human right instruments ratified by the country. ${ }^{57}$ Against these legal frameworks, "large-scale land transfer in Ethiopia displaces poor and vulnerable populations, which in turn exacerbate poverty and food insecurity". ${ }^{58}$ It snatches away fertile land ideal for cultivation from the farmers and curtails their ability to feed themselves. ${ }^{59}$ Moreover, forest clearing for agricultural purposes has further undermined food security as resources

52 Oakland Institute (n.13)40.

53 Ibid 43

54 Ibid.

55 See UDHR, art 25; ISECR, art 11; Article 15 of Declaration on Rights of Peasants.

56 The right to food is a pre-condition to exercise the right to life and right to an improved standard of living recognized under Articles 15 \& 43 of FDRE constitution.

57 In this regard, Article 9(4) of FDRE constitution states that international treaties signed by the country are integral part of the country's law of land.

58 Grant \& Das (n.10) 12 .

59 Ibid. 
like nuts, seeds, fruits, and wildlife provide sources of food when harvests fail. ${ }^{60}$ Even worse, such commercial agricultural investments are designed for export and not for local consumption to ensure food security in Ethiopia.

\subsubsection{The Right to Development}

As discussed under section 2 above, the right to "development" is proclaimed as an inalienable right under the Declaration on the Right to Development (DRD ${ }^{61}$ and further reinforced directly or indirectly under the declaration on right of indigenous people and declaration on right of peasants. Such right to development and improved standards of living is also recognized under Article 43 of the FDRE Constitution. However, the existing wave of large-scale land investment in the country seriously undermines and nullifies all elements of right to development of the local community. As highlighted above, large-scale land investment in Ethiopia results in forced eviction of local community without their consultation and effective compensation. It is obvious, therefore, that the livelihood of the rural community in Ethiopia is closely linked to access to land, and accesses to land is a precondition for improving their living standard and achieving sustainable development. Hence, it follows that forced eviction that is short of adequate compensation or replacement land directly affects people's right to development. Moreover, the revenues collected from large-scale land investment rarely provide direct benefit to affected communities.

\subsubsection{The Right to Culture}

This right is clearly recognized as human a human right under various binding and non-binding human right instruments as well as the FDRE constitution. ${ }^{62}$ However, the practice of large-scale land investment in Ethiopia poses serious impacts on cultural and religious rights of local communities. For the Ethiopian, "loss of land, whether farmland, communal or grazing areas have religious or cultural value". ${ }^{63}$ Since

60 Oakland Institute (n.13).

61 While none of the three bills of human right made express reference to a right to development, many of the principles and rights specified therein are crucial to an understanding of such right.

62 See Article 27 of UDHR; Article of 15 of ICESCR; Article 26 of Declaration on the Right of Peasants; Article 41 of FDRE constitution.

63 Oakland Institute (n.13)38. 
their cultural and religious rituals are enjoyed in relation to their ancestral land, eviction of the indigenous community from the land is simply uprooting identity of the people from their ancestral heritage ${ }^{64}$ It is also reported that the "investor uprooted large trees located on religiously symbolic site frequently used for cultural and religious events." 65 That way, large-scale land investment in the country seriously affects the cultural and religious rights of local communities, and these are recognized under the FDRE constitution and the international instruments.

\subsubsection{Labour Rights}

Labour rights have been explicitly recognized under relevant international instrument as well as the Ethiopian law. The UDHR and the ICESCR affirm the right to freely choose an occupation, to enjoy a just and favourable remuneration, to work in safe and healthy conditions, and to form and join a trade union. ${ }^{66}$ However, the practice of large-scale land investment in the country undermines the labour rights of workers. It is shown that local communities hardly benefit from employment opportunities as most employees often come from other parts of the country ${ }^{67}$ Even in areas where local community members are employed, majority of the jobs are labourer, seasonal and short term positions in which workers are not fully paid, or the wages are very low and in no way commensurate with the service rendered by the workers, nor do they guarantee the cost of living. ${ }^{68}$ Moreover, the large-scale land investor is reported to discriminate against and harass female employees, demoralize the workers, deny them access to healthcare and safety conditions, provide no training opportunities or skills transfer, and undermine other rights of workers. ${ }^{69}$

\subsubsection{Environmental Rights}

Despite the absence of international human rights treaty proclaiming right to clean and healthy environment, the right is clearly recognized

64 Abebe (n.11).,

65 Ramato (n.10)24.

66 See article 23 of UDHR; art 6-7 of ICESCR.

67 Rahmato (n.10) 22.

68 Ibid.

69 Ibid 25. 
under Article 18 of the Declaration of Right of Peasants and Article 44 of the FDRE constitution. Moreover, the environmental rights could be implied under right to life, right to health and other related rights recognized under international bills of human rights. However, largescale land investment has seriously affected the environmental rights of local communities in Ethiopia. The potential environmental damage resulting from large-scale land investment in the country includes destruction of soil fertility, loss of biodiversity and draining of wetlands, air and water pollution, spread of invasive alien species, and toxic wastes. ${ }^{70}$ Aggressive use of fertilizers and other chemicals by large-scale agricultural investors may also affect the environment. That way, largescale land investment without proper environmental impact assessment in the country could threaten the environmental rights of local communities.

\subsubsection{The Right to Self-Determination}

This right is boldly recognized under different international human rights instruments ${ }^{71}$ as well as the FDRE constitution. ${ }^{72}$ The People's right to self-determination includes the "right to exercise the inalienable right to full sovereignty over all their natural wealth and resources and the right to freely dispose of their natural wealth and resources, and by virtue of that right people freely determine their political status and freely pursue their economic, social and cultural development". ${ }^{73}$ Article 1 of both ISESCR and ICCPR states: "no people may be deprived of its own means of subsistence". However, in Ethiopia, the arrival of large-scale land investor marginalized and forcefully uprooted the people from their land, effectively denying their right to self-determination. ${ }^{74}$ It is believed that "there is a strong correlation in many societies between the decisionmaking powers that a person enjoys and the quantity and quality of land rights held by that person". ${ }^{75}$ Hence, such eviction from land and other natural resources through the decision of federal government affects people's right to self-determination.

70 Ibid 44.

71 The right to self-determination enshrined under Article 1 of both ICCPR \& ICESCR. It is also referred under other soft laws such as DRD, Declaration on Right of Indigenous People, Declaration on Right of Peasants.

72 Article 39 of the FDRE constitution.

73 Articles 1 \& 2 of ICCPR; Articles 1 \& 2 of ICESCR.

74 Abebe(n.11)884.

75 Ibid 882. 


\subsection{Procedural Rights at Stake}

Procedural rights refer "to constitutional and statutory legal rights that focus on the procedural aspects of governance, and are essential to realize the substantive rights". ${ }^{76}$ These procedural rights principally involve the right to public participation, prior informed consent and access to information and justice, and these rights are recognized under various binding and non-binding international instruments ${ }^{77}$ and the FDRE constitution. ${ }^{78}$ However, the existing wave of large-scale land investment in Ethiopia operates in disregard of indigenous peoples and local communities' active participation in decision making, denying them access to key information about land deals, and abrogating their constitutional right to free and prior informed consent, compensation and legal redress. ${ }^{79}$ In practice, large-scale land investment deals are secretly negotiated and permitted by the federal government, the local peoples are never consulted, and even worse, the local officials are not consulted in most of the decisions to transfer the land to investors. ${ }^{80}$ Moreover, none of the victims is able bring their matter before the court and obtain effective remedy or redress.

\section{IMPLEMENTING THE RIGHTS-BASED APPROACH TO LARGE-SCALE LAND ACQUISITION GOVERNANCE IN ETHIOPIA}

A human rights approach is a "conceptual framework ... of human development that is normatively based on international human rights standards and operationally directed to promoting and protecting human

76 JCN Ashukem, "A Rights-Based Approach to Foreign Agro-Investment Governance in Cameroon, Uganda and South Africa" (PhD Thesis, North-West University, 2016).

77 These procedural rights are stressed under different international instruments, including the bills of right, DRD, Declaration on Rights of Indigenous People, the FAO Principles, and the AU principles. See discussion under section 2.

78 Article 43(2) of the FDRE constitution states: "Nationals have the right to participate in national development and, in particular, to be consulted on policies and projects affecting their community"; Article 92(3) of the constitution adds: "People have the right to full consultation and to the expression of views in the planning and implementations of environmental policies and projects that affect them".

79 Nykiaw Ochalla [2013]< https://intercontinentalcry.org/ethiopias-land-grabs stories-displaced-20830> accessed 9 July 2019.

80 Oakland institute(n.13). 
rights." ${ }^{81}$ In essence, the rights-based approach integrates norms, standards and principles of the international human rights system into the plans, policies and processes of development. ${ }^{82}$ The rights-based approach sets the achievement of human rights as an objective of development project and considers human rights as benchmarks of development policies and programmes. ${ }^{83}$ It pinpoints "right holders and their entitlements and corresponding duty-bearers and their obligations, and works towards empowerment of the rights holders to make their claims and of duty bearers to meet their obligations" ${ }^{84}$ The key element of rights-based approach includes express linkage to human right, accountability, empowerment, participation, equality and equity, and attention to vulnerable and marginalized groups in the community. ${ }^{85}$

In the context of large-scale land investment governance, human rights based approach entails integration of human rights issues in the investment regulation and administration. A rights-based approach to large-scale land investment governance encompasses the "responsibilities of development actors to respect, protect, and fulfil fundamental rights of people involved with or affected by large-scale agricultural land deals as well as the need to uphold human rights during large-scale land investment regulation". ${ }^{86}$ This suggests that applying the right based approach to large-scale land investment governance is expected to be a means to ensure and promote inclusive, transparent, responsible and sustainable large-scale land investment activities, and protect, respect and fulfil both substantive and procedural rights of those communities potentially affected by such investments. ${ }^{87}$ Hence, the implementation of rights-based approach to large-scale land investment could serve as a tool to ensure that large-scale land investment contributes to socioeconomic improvement of the people while respecting their fundamental rights.

In Ethiopia, there is a constitutional basis for human rights based approach that provides legitimacy to implement rights-based approach to large-scale land investment governance so as rectify the tragic human

81 HRBA Portal(n.2).

82 Ibid.

83 HRBA Portal(n.4).

84 HRBA Portal(n.2).

85 Ibid.

86 Ashukem(n.76)114.

87 Ibid. 
rights consequences of large-scale land acquisition prevailing in the country. The human rights based approach is clearly articulated under the preamble of the FDRE constitution which recognizes the fulfilment of human rights as a precondition for the realization of economic and social development. ${ }^{88}$ In addition, Article 43 of the constitution, which recognizes right to sustainable development ${ }^{89}$ and public participation and consultation in development process as human right, reinforces rightsbased approach to development.

Human rights, as an integral part of development, can also be inferred from chapter three of the constitution, which provides a list of inalienable and inviolable human rights and dictates the interpretation of these rights in accordance with the international human rights instruments to which the country is party. In light of this, Ethiopia ratified major international human rights treaties, including the ICCPR and ICESCR. All these ratified treaties are considered an integral part of the law of the land, reflecting the country's commitment to human rights. ${ }^{90}$ By so doing, the Constitution subscribes to fundamental human rights of Ethiopians as derived from international human right standards, and this could be implemented in large-scale land investment governance.

Even though the ideology of developmental state ${ }^{91}$ that the ruling party claims to be pursuing has the potential to frustrate the right to sustainable development enshrined in the constitution, principles of the

88 Para $1 \& 2$ of the preamble reads "We, Nations, Nationalities and Peoples of Ethiopia: Strongly committed, to building a political community founded on rule of law and capable of ensuring lasting peace, guaranteeing democratic order, and advancing our economic and social development; Firmly convinced that the fulfilment of this objective requires full respect of individual and people's fundamental freedoms and rights..." As can be inferred from this preambluar objective, advancing economic and social development with due respect to fundamental right and freedom of all individuals and people is considered key objective of establishing Ethiopian Federation.

89 The 2002 Johannes Barge Declaration on Sustainable Development considers Sustainable development as embracing three mutually reinforcing and interdependent pillars; economic growth, social development (including human right protection) and environment protection.

90 See Article 9(4) of the FDRE constitution.

91 Developmental state stresses "economic growth first right next" paradigm with the flawed assumption that civil rights and political freedom make little sense in a society hit by poverty. See Assefa Fiseha, "Development with or without Freedom", in "Human Right And Development: Legal Perspective from and for Ethiopia", 101 -138 (Eva Brems, Christophe Van der Beken and Solomon Abay Eds., International Studies of Human Rights; volume 111, 2015) 144. 
rule of law dictates that the ruling party give up the ideology and uphold the rights-based approach to investment governance advocated by the constitution. This is because the ideology lacks constitutional legitimacy as the constitution guarantees all rights without prioritizing one over the other while the ideology prioritize economic growth over civil and political freedom. ${ }^{92}$ Indeed, economic growth is not an end in itself as ultimate goal is improvement of the living standard of people based on respect for human rights and public participation. ${ }^{93}$ Consequently, development actors of the government should not be influenced by the narrow pursuit of a developmental state by prioritizing economic gains of large-scale land investment over the human rights of local communities while promoting, regulating and administrating large-scale land investment.

Hence, taking this firm recognition of rights-based approach under the constitution as opportunity and given the existing human right impacts of large-scale land investment in the country, it is extremely useful and workable to adopt a rights based approach to large-scale land investment in the country. To this end, the government and all stakeholders engaging in large land deals in the country should work towards effective implementation and integration of both substantive and procedural rights incorporated under the international bills of human rights, the pertinent UN declarations, and the FDRE constitution, and guided by the UN Guiding principles on business and human rights, FAO Principles, and AU Guiding principles in all large-scale land deals. ${ }^{94}$ In light of this, the human right based approach requires the government to establish a system of large-scale land investment that is grounded on principles of good governance. ${ }^{95}$ Good governance, in the context of

92 Ibid 133.

93 See Article 43 of the constitution.

94 As can be inferred from the discussion under section 2 above, all instruments support a rights-based approach to large-scale land investment and guide toward and call for a need to respect, protect, and fulfil both substantive and procedural rights recognized under the international bills of rights and other specific instruments in the course of large-scale land deals. In most cases, the rights and principles or guidelines provided under each instrument overlap, reinforce and complement one another in the achievement of one and the same goal.

95 The good governance for large-scale land investment entails the existence of transparent, efficient, democratic, participatory, inclusive and accountable processes and institutions in formal and informal regulatory setting that govern 
large-scale land investment, requires the government to protect, respect and integrate all potentially invoked substantive and procedural rights of local and indigenous communities discussed under section 3 of this paper.

In particular, effective implementation of procedural right to public participation, prior informed consent, access to information and justice as well as effective remedy for violations of rights in the course of largescale land deals are at the heart of rights-based approach to large-scale land investment governance. Effective implementation of these procedural rights is important not only as an end in themselves but also as a means to safeguard substantive rights of affected communities. For instance, implementation of right to access to information could provide opportunity for the communities to take important decisions on matters that affect them in view of the need to protect and enhance both their procedural and substantive rights. Effective enforcement of right to public participation could also enable local communities to effectively engage with the relevant authorities during large-scale land investment decision making processes with the hope of preventing the harmful impacts of such developments or seeking redress after the event. Moreover, respect for and the promotion of human rights, whether substantive or procedural, can be effectively guaranteed by means of access to justice. Hence, the government shall disclose all information about large-scale land investment deals to local communities and all affected stakeholders as early as possible, ensure their effective participation, and stick to their prior informed consent in all courses of large-scale land investment deals and its implementation.

Moreover, the government should take necessary steps to ensure that its large-scale land deals respect substantive human rights of local communities, including land rights, right to food, right to development, right to culture, labour rights, environmental rights, and right to selfdetermination enshrined under the relevant international instruments applicable to responsible agricultural investment. ${ }^{96}$ Most importantly, the government should recognize the existing use or ownership rights to

large-scale land investment initiatives while protecting the rights and interests of affected local communities according to the minimum standards set by law and legal contracts. See Ashukem(n.76)114.

96 These are the main substantive rights of local communities seriously undermined by the practice of large-scale land investment as discussed under section 3 above. 
land, whether statutory or customary, formal or informal, communal or individual. ${ }^{97}$ This entails the identification of all rights holders, legal recognition of all rights and uses, negotiation with land holders/users, fair and prompt payment for all acquired rights, and independent avenues for resolving disputes or grievances. ${ }^{98}$ In line with this requirement, the government should stop its bad practice of expropriating land before it can be transferred to investor, thereby blocking direct negotiation between the right holder and investor. The Government should also be honest in providing compensation and relocation assistance to all those displaced due to large-scale agricultural investment. By respecting all these elements of land right, the government can indirectly promote the related rights, right to self-determination, right culture, food rights, and right to development.

With a view to protecting the other frequently invoked rights, such as right to development, right to work, right food, and environmental rights, ${ }^{99}$ the government should put in place laws, regulations, directives or clauses in lease agreement addressing large-scale land investor's obligation regarding performance requirement, ${ }^{100}$ benefit sharing, labour and environmental standards, and human rights obligation in general. Hence, through these arrangements, investors should be required to establish and promote farming systems that are sufficiently labourintensive to contribute to employment creation, and prioritize local community in employment opportunities, provide adequate wages and protect the labour rights of agricultural workers consistent with the applicable ILO instruments. In addition, there should be mechanisms that encourage rights holders evicted as a result of land acquisition to

$97 \quad$ FAO principles, Principle 1.

98 Ibid.

99 See requirements under FAO principle, principles 2; AU principles, Principles 1.

100 In particular, performance requirement such as local content requirement that mandates the large-scale agricultural investor to prioritize local community in employment opportunities; requirement to achieve a specific level of local jobs, local selling of a certain quantity of its crops to support food security; requirement to engage in training workforce and technology/ skill transfer to local farmer; requirement to conduct research and development; achieving better environmental or social outcomes, infrastructural development; and requirement to form a joint venture with local partner/farmer to make the investment could be used to make largescale investment in line with and support the local community's right to development, right to food, right environment, and other rights. 
be shareholders in the investment in question or make the affected community a direct beneficiary of the investment agreement revenues, or provide other means to ensure benefit sharing between the investors and the community to assist their right to development, and then right food.

The other important measure that government needs to consider before granting concessions to large-scale land investors is to design an investor's obligation scheme which mandates the investor to conduct human rights impact assessment. ${ }^{101}$ The impact assessment should cover all potential human right impacts of the proposed investment, including land right, right to food, right to culture, labour rights, rights of indigenous peoples, and environmental rights. This will ensure that the investor respects the human rights of the local community. The assessment should be made in consultation with affected people to secure their free and prior informed consent; be open to the public, media, and civil society, and ensure their access to its recommendations in the assessment, review and results of the monitoring processes. It should also provide effective grievance procedure and effective remedies for those whose rights are violated or who may suffer harm as a result of the investment. ${ }^{102}$ Moreover, the assessment should be a requirement for application, issuance, renewal and expansion of investment permit.

Finally, the government should establish efficient and transparent monitoring, evaluation, and dispute resolution mechanisms that ensure accountability of all stakeholders. ${ }^{103}$ The authority in charge of this activity should review the plan of the impact assessment and use it as a baseline for the ongoing monitoring of the performance of investments. Moreover, noncompliance with the plan should be considered a ground

101 Human right impact assessment (human rights due diligence) is defined as "the process through which companies 'identify, prevent, mitigate and account for how they address their adverse human rights impacts', and it 'should include assessing actual and potential human rights impacts, integrating and acting upon the findings, tracking responses, and communicating how impacts are addressed" UN guiding Principles for Business and Human rights, principles 17.

102 Ibid; AU principles, principle 15

103 See FAO principles, Principle 3; AU principles, principle 8; Even though the Ethiopian Agricultural Investment Land Administration Agency is currently entrusted with similar function, the agency is meant to facilitate and promote the investment for economic growth ignoring its social and human right dimension. 
for revocation of investment permit. Non-compliance with the plan should also entail investor's accountability for any harm sustained by the community. Additionally, there should be strong, accessible, transparent, and speedy mechanisms to resolve all disputes arising from large-scale land investments. What is more, the government should invest in empowering the rural community members to know their rights, and be able to organize themselves to safeguard their human rights. ${ }^{104}$ The government should also encourage civil society, activists, nongovernmental organizations, media and all other human right actors to promote the rights of rural communities in all courses of large-scale land investment.

\section{CONCLUSION}

Human rights are universal, inalienable and inviolable rights naturally gifted to all human beings, thus imposing on the state a duty to promote, protect and respect these rights. However, the new wave of large-scale land investments reportedly undermine human rights of local communities in Africa, particularly in Ethiopia. Ethiopia has been chosen for this large-scale deals considering availability of cheap labour and arable land, and the government's support of such investments. The Ethiopian government has welcomed these large-scale investments with the expectation that it would boost productivity, provide job opportunities and transfer technologies to local farmers. Yet, the critics are concerned more about human rights impacts of such investments on local community. This article has explored the human right impacts of large-scale land investment in Ethiopia and suggested a key forward to reach a win-winwin solution.

Accordingly, from the reviews and analysis of the relevant international instruments, soft laws, and principles applicable to largescale land investment as well as FDRE constitution, the article established that these instruments recognized substantive and procedural rights and dictates respect and integration of these rights in the development process. To the contrary, the article confirmed that large-scale land investment in Ethiopia operates at the expense of the local community's substantive rights, including land rights, right to food, right to development, right

104 AU principles, principle 10. 
to culture, labour rights, environmental rights and right to selfdetermination. Moreover, such large-scale investment disregards procedural right to participation, prior informed consent, and access to information and justice.

Relying on relevant international guidance and requirement under the FDRE constitution, this article advocated a human rights based approach to large-scale land investment governance that respects and integrates both substantive and procedural rights of affected community. In particular, the government should ensure respect for land rights, and propose laws or clauses in lease agreements that address investor's obligation regarding performance requirement, benefit sharing, labour and environmental standards, and human right impact assessment as required under relevant international guidance to make sure that its large-scale land deals respect and promote all substantive rights at stake. It should also stick to the procedural right to public participation, prior informed consent, and access to information and justice. Lastly, the government should facilitate effective monitoring and dispute resolution mechanisms and empower local community and other stakeholders to safeguard the rights of affected community members. 